\title{
A CASE OF LARYNGEAL CHONDROMA
}

By

Toshiyuki NISHIOKA, SAchiko MARUYAMA

The Oto-Rhino-Laryngological Department of Nara Medical College

(Director: Prof. Sadao UTSUMI)

TEIzo MUKAI

The Oto-Rhino-Laryngological clinic of Yao Municipal Hospital

A rare case of chondroma of the larynx is herein reported in which the neoplasma originated in the cricoid cartilage extended to left arytenoid region, and it obstructed severly the laryngeal cavity. Total laryngectomy was necessary in this case.

Some problems on diagnosis and therapy of this desease are discussed in refering the bib. liographies.

\section{喉 頭 軟 骨 腫 症 例}

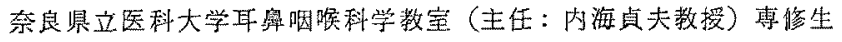

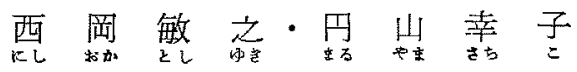

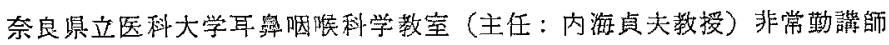

八尾村立病院（院長：林秀雄博士）耳鼠咽㙏科医長

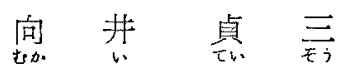

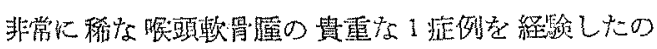
で，先人の報告炕追加すると同時に，文献的ならびに臨

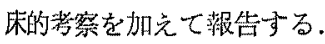

$$
\text { 岩○ノ○69才 然蔀 }
$$

昭和 37 年 1 月㥧上り仮声に氛付き，潮次增雭し，同 年9月頃より呼吸困難も加子り，10月8日外来学訪れ

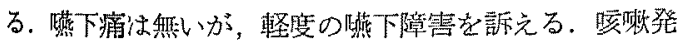
作・喀痰も無く平熱である.

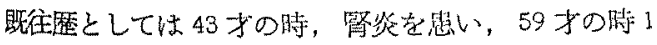
餙立らくらみを䯭じたことがある。

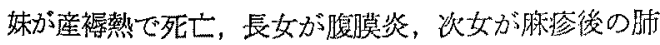

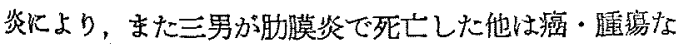
ど特記すべき家族迶拜し。

全身状態としては，体格肥渵型で眼臉結膜に頚血はな

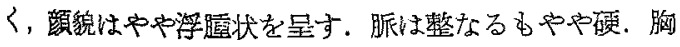

部打診するに左心が孚頭部より約 2 横指左方に肥大する も㯖診で性著変㒛めず，腹部皮下脂游はよく発達するす

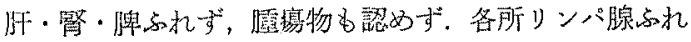

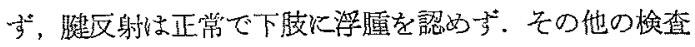
所晃は表 1 の加し.

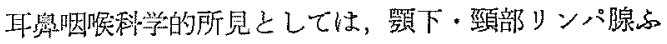
れず，前頸部に特別暴常を認かず。

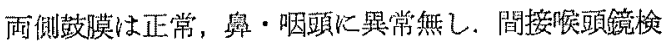
查で因 1 の如く，左披裂部扣よび仮声带と思われる部分

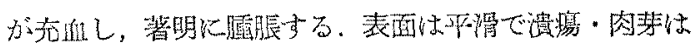
認めず。これら腫脹部分は発声に際し，浑動は完全に淂

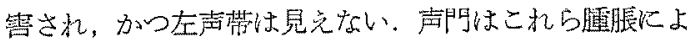

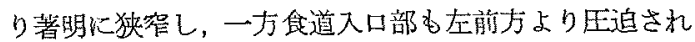
た状態になつている。

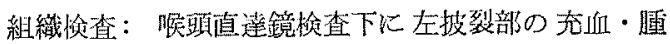
镺部和よびさらに深部の声門と思われる場所より再三組 


\section{表 1}

血液：

\begin{tabular}{|c|c|c|c|c|c|c|}
\hline 赤血球数 & 381 万 & \multirow{2}{*}{\multicolumn{4}{|c|}{$\begin{array}{l}\text { 血绝素（サ゚ーリー） } \\
\text { 血色尜係数 }\end{array}$}} & $80 \%$ \\
\hline 白血球数 & 6400 & & & & & 1.05 \\
\hline ヘマトク & $1.36 \%$ & \multirow{7}{*}{$\begin{array}{l}\text { 息 } \\
\text { 液 } \\
\text { 像 }\end{array}$} & & 酸 & 球 & \\
\hline 血 小板 & 21 万 & & & 基 嘫 & 好 & \\
\hline 出血時間 & 4分 & & 幼 & 若 & 型 & \\
\hline 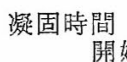 & 5秒 & & 桿 & & 状 & \\
\hline 完䊽 & 30 秒 & & 分 & 藥 & 状 & 52 \\
\hline 血 液 型 & $\mathrm{O}$ 型 & & & ン パ & 球 & 35 \\
\hline 反応 & 陰性 & & & $\begin{array}{l}\text { 核 細 } \\
\text { ラズマ縕 }\end{array}$ & $\begin{array}{r}\text { 胞 } \\
\text { 田胞 }\end{array}$ & \\
\hline
\end{tabular}

尿：蛋白(一) 糖(一) 細胞(赤血球認めず) ウロビリノーゲン正常

蕒：奇生虫卵認めず

血压： $188 \sim 76 \mathrm{mmHg}$

EKG：PR 時間 0.17 秒 QRS 時間 0.08 秒 電気軸 left axis deviation 律整 T波：一般に平低 ${ }^{2} \mathrm{~T}_{\text {III }} \mathrm{T}_{\mathrm{aVF}}$ 陰性 やや心筋障害を認める

胸部X線：左心の肥大を認めるも肺野には結㤥性腫瘍 性陰影は認めず。

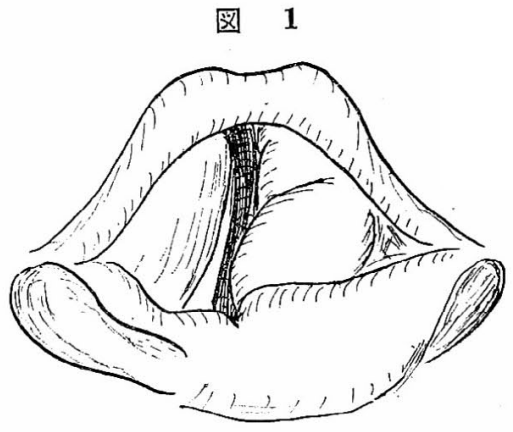

織切片を採取し，病理検査を依頼する，当該深層部は消 息子でかなり堅くられる。組織像は図 2 の如く上皮細胞 層の肥厚と軽度の炎症を認めるも，悪性嗹瘍と決定し得 る像を発見し得ず.

$\mathrm{X}$ 線㭘査：食道の造影・透視特よび写真によつて食 道入口部前壁の腫脹, 約 $3 \mathrm{~cm}$ の長さに亘る辺縁の凹凸 不整と当該部の狭窄を認めた（図 3). 喉頭の X 線側面 像では喉頭部軟骨に囲まれた部分にはびまん性の陰影の 他に比較的濃厚な部分が散在してみられる。

左披裂部扣よび仮声带の運動の完全なる障害，食道X

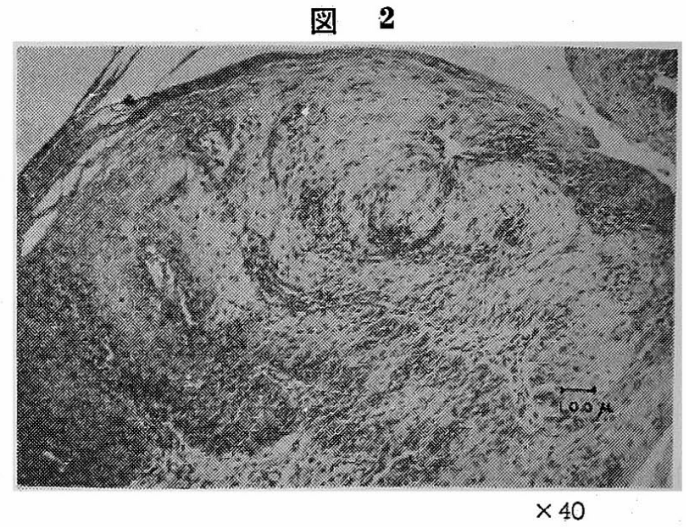

図 3

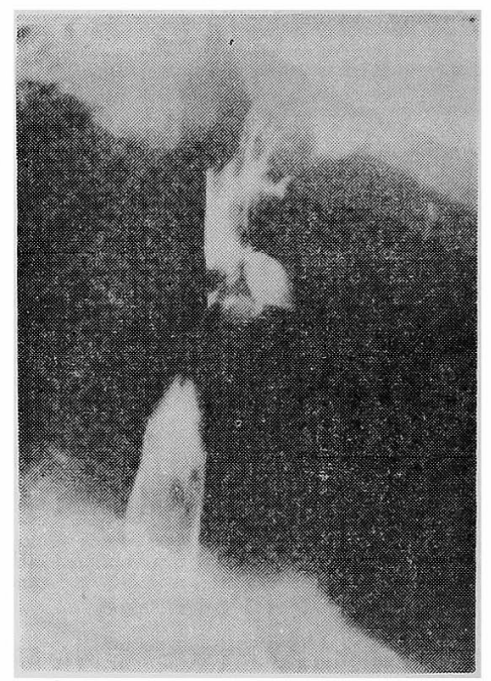

線㭘査で前壁の凹凸不整执よび狭窄の像を示すことか ら，採取し得た組織片には決定的な恶性腫痬像は発見で きなかつたが，臨休的に喉頭腫瘍と決定，またリンパ腺 転移は認めず軟骨通を考えたが同時に悪性腫瘍にも疑い を执いた。 とりあえず10月10日入院せしめ，同時に内 科的に循環系に対する治療を受けた。

手術所見：10月 17 日先づ気管切開施行し, その切 開部より雨管してエーテルによる半閉鎖循環麻酔下に, 先つ㗹頭截開術を施行する. 啹頭を露出して内視するに 左側披裂部には拇指頭大に腫脹し, 輪状軟骨は全周に亘

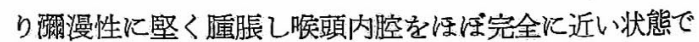
閉塞している，そこで止むなく咲頭全摘出術に切替省， 気管瘦に No. 12 カニニーレとまた鼻腔より胃ゾンデを 插入して術を終る。 
図 4

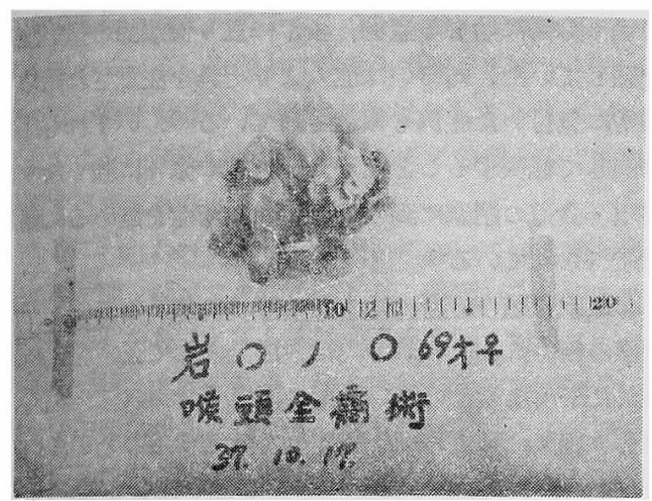

摘出物：後壁に执いて切開するに図 4 の如く腫瘍物 （長さ $4 \mathrm{~cm}$ 横径 $2.3 \mathrm{~cm}$ 前後径 $2.0 \mathrm{~cm}$ ) は輪状軟骨より 発し，喉頭後面の縱断面は軟骨がびを儿性に肥厚腫脹し てレンズ状を呈する，眮脹はとくに左㑡寄りに強く上方 は左披裂部に及び癒着する．また後方すなわち食道前壁 の粘莫はこの而瘍の厈迫のためやや萎縮していた，また 輸状䖝骨及び左披裂部腫脹のため, 左側声帯拉よび仮声 带は晱頭前庭部の上外方に圧迫されて埋没してしまい， 知頭鏡下に仮声帯とみえたのは輪状軟骨の軟骨皇の一部 であつた．乙かし搌頭内・食道内粘膜には潰演を認め ず，腯瘍の割面は硝子様半透明の軟骨から成り，滑らか であり，やや粘液性に湿潤している，中心部は䯚様にな り，褐色を帯びた小さな空洞化がみられ，わ゙かかながら 粘液性物を合み一見して軟骨堙の状態を示す.

绎過：術後順調に絟過し，8 日目に鼻腔ゾンデを拔 去, 10 月 27 日上り食道発声の綀習を開始し，添ぼ家族 飞理解できる程度になつて11月10日退院，以後現在迄 約 4 年半再発の微なく日常生活を営えでいる.

組織学的所見：軟骨腯組織は結締織線維より成る被 露に境され（図5，6），周辺部には化骨した部分も発見 する，㳄骨細胞は周辺には密度が高く，中心部に及ぶに 従つて密度を減じ, homogen の硝子様にみえる軟骨基 組織中に分布する，強拡大で軟骨細胞を観察するに（図 7), 被擎の中に 1 個も乙くはそれ以上の幼若軟骨細胞を 包含し，多染性を示し，中には泡状变化などの退行变性 がみられ，核の消失した細胞，また被裂を欠いた幼若 細胞など多様性を示す，腫瘍の中心部で肉腿的に褐色醀 様火見克る部分は軟骨細胞がまぱらで，乙かも退行变性 強く，㳄骨基組織も壤死になり空洞化している。

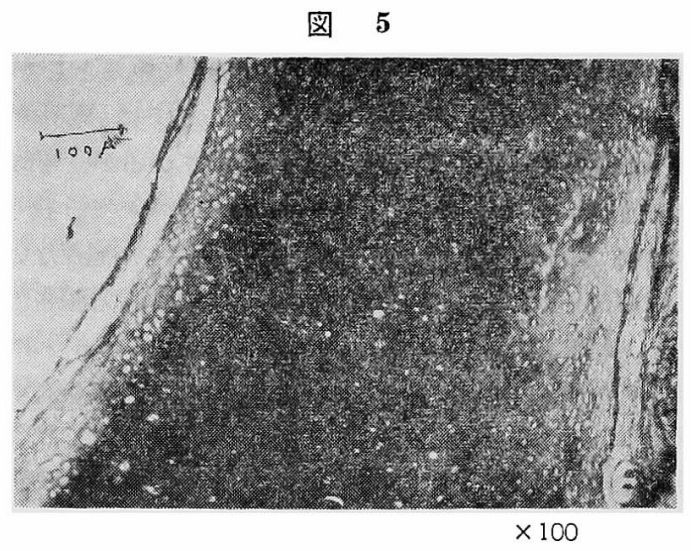

図 6

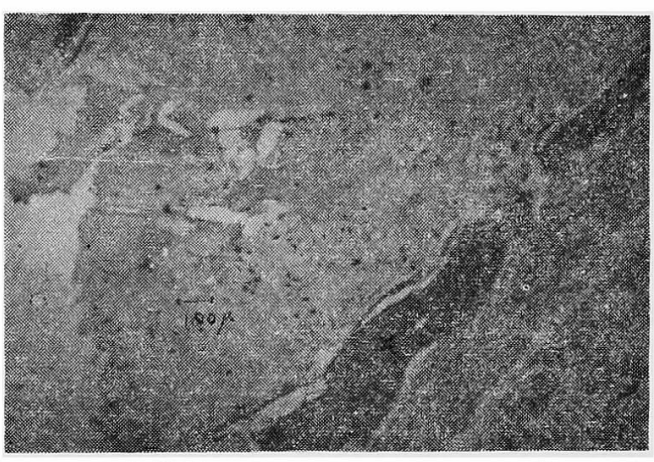

×化骨部

$\times 40$

図 7

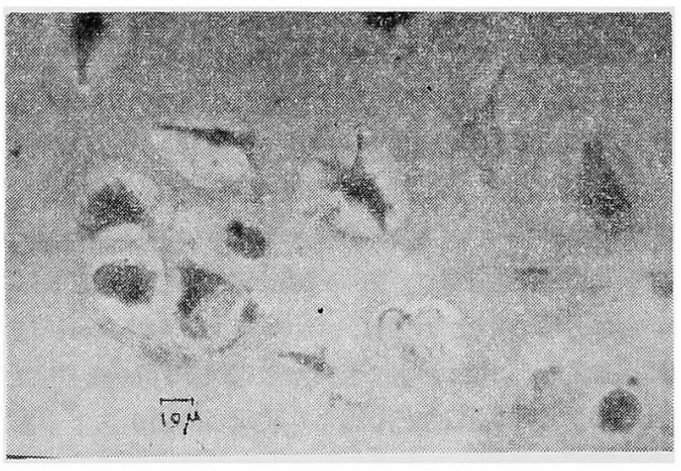

$\times 400$

考察

喉頭の軟骨堙は Heusinger によつて1822 年に始めて 報告され，Moore ${ }^{8)}$ は 1925 年に到る100年余の間の文

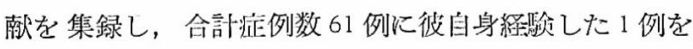

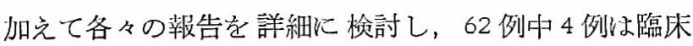




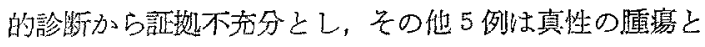
いうよりもむしろ明らかに hypertrophyであるとして， いずれる症例合計数より差引いている。ささらに Walter 13）は1959年迄老合計して97例と述べているが，唵頭

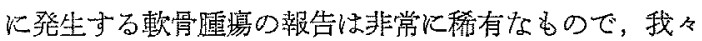
の集録し得大籁囲で1966年迄には98 例にしか過ぎない （表2），他方我が国の耳鼻呢咽科学領域に和ける郝告で は，これ火比較的近い疾患として，知江田 - 村田 7) よつて昭和 3 年報告された披裂䖝骨に小豆大で茎を有す る ecchodrom の1例発晃するのみで，本論文に報

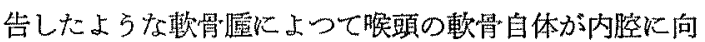
い增殖し，海とえど完全に閉塞し，㩔頭全摘出術を必要 とする状沇であったような症例の報告には桉していな i.

\section{表 2}

\begin{tabular}{|c|c|c|}
\hline 主な報告者 & 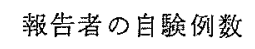 & 合計症例数 \\
\hline Heusinger (1822) & 最初の1症例の報告 & \\
\hline Moore & 例 & 53 例 \\
\hline (1932) & 例 & 77 例 \\
\hline Walter & 例 & 97 例 \\
\hline Hora et al (1961) & 例 & 98 例 \\
\hline
\end{tabular}

男女間に和する発生覑度については特に女炕少く Moore は男は女好対し，5：1，Hora 拈よび Mc Call はそれぞれ6：1と報告しているのに対し，Walter は 97 例の内訳について 10:1という比率を举げている6).

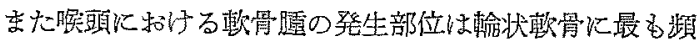
度が高く，会厭軟骨，披裂軟受の順に頻度が少くなると いわれている5).

本症の分類としては先す Virchow (1836)10) は病理

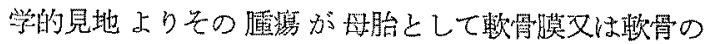
いずれに起源するかにより, ecchondrom と enchodrom とに分ける柴を示暛し，Alexander や Moore は 更に追加的な subgroup を作つた。 な Tobeck ${ }^{12)}$ は

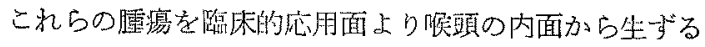

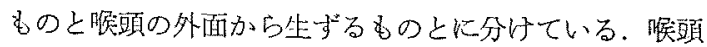
の内面に增㥀する場合と外面儿向つて增殖する龧合，こ

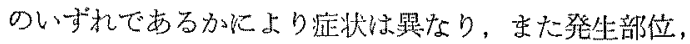
瑟性度によつて初発症状が变化するが，栕して晥頭の内

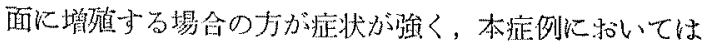

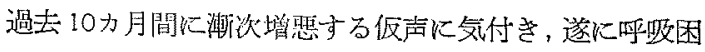

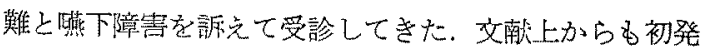

症状として仮声に気付く症例が最も多いが，また無痛性

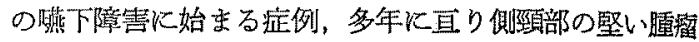
を感じていた，あるいは他人よりそれを注意され始めて 異常に気付いた症例子報告されている4). いずれる証状 は決して軽快することなく，一方的に徐々に強くなり， 昨頭・食道の閜塞に到り患者自身重篤珄を認めるに到る と述べられている6).

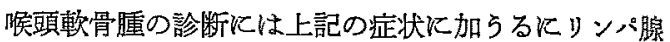
転移の無いこと，涘頭の内視鏡所見として正常粘膜に玿 われた平滑な潰痬の無い㙞瘍，消息子でられると堅く， 通常 1 側文は両側の声帶の運動它障害することが多い。 $\mathrm{X}$ 線所見では䢮癔の密度に応して濃い陰影を認めるこ とにより，とさに住余にわたり経過を観察すること似 よつて䛦断を下し得るとも云われている4) 10). しかし 涘頭内面に発生するものでは潰陽を作ることるあり，と くに試験切片採取した後は胒頭所見が䄍雑化し，また X線検查でる軟骨蕾としての疑いを持たない場合は撮影

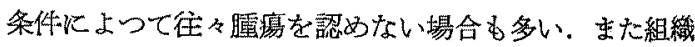
標本でも腫瘍が有茥ポリープ状でない限りとくに腫煌が 声門下に存在していて，直達鏡下に錳子で組織片を採取 するとき，大抵の場合禹骨部迄深く採取することが不可 能で，術前には決定的な組織像を得られず涘頭を切開 し，その術中あるいは㻠頭を摘出した後その摘出物より 埰取した組織片の組織検査によつて始めて軟骨尰と確定 される埸合も多い(10)。診断の困雉性を証明するものとし て，初め中枢神経系の末期梅毒のための声帯運動障言

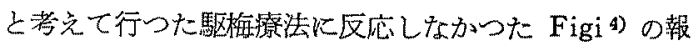

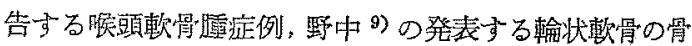
歌骨遮を思わせた迷在性甲状腺乳嘴状腺癌症例，術前

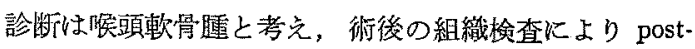
cricoid epidermoid carcinoma $と$ 確定した Orton ${ }^{10}$ の稂告する症例などがある。

治療の方針は発生場所，大きさ，倁頭への附着の仕

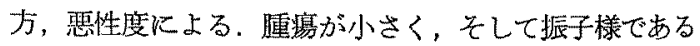

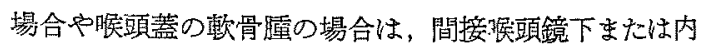
視鏡下に除去すべきであるう．Figiによれば，要すれれば 先づ気管切開で呼吸困難を緩和して特き，経過を観察し

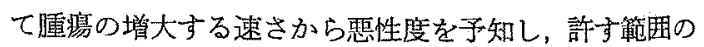

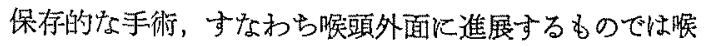
頭内面の粘膜を筫害せずに軟骨堙だけを剔出し，あるい は喉頭截開衍により，または㩔影の軟骨片側のみを除去 する事を推賞しているが，同時にまた彼は始め小さい範 因の切除予定で開始した手術が，手術を進めるにつれて 
もつと広簐な手衔をすることが必要であることがわかり 途中で手術方針を変更するよらな手術中の危険性につい ても我めている，垁際上は軟骨の境殖は広範で，時にリ ンハ管・静脈を通じて進展する場合るありれ，Moore はこのような腫漡の治㙩は同一場所の癌腫と全く同様に 手術すべきであるとしている。

ここにわれわれが報告した婝例に打いては術前組織学

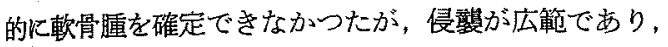
同時飞頻度から考えても悪性腫瘍をも強く疑つていたの で観察期間は比㩤的短く，手術開始に先立ち啒頭全摘出 術わ予相しながら気管切閉, 気管内捜管による半閉鎖循 環麻酔下に先づ䐅頭截開術から始めた，知頭内面を露出

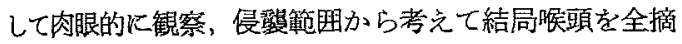
出することにした．文献によれば4)11）診断に慎重を期 す余り、ラジウム療法を行いながら年余にわたり経過観 察していたが，その間に余病を併発して自宅死亡する上 いら不幸な結果に終つた軟骨腫症例，むた右前頸部に発 し絽過観察中に左側以も転移してしまい診断は確定した が手術を希望せず来院しなくなつた应例などが述べられ ている。また保存的な手術後に再発し，結局は咲摘を必 要としながらも再手術を拒否する患者についての報告を 見るとき，われわれ臨床家としては余程の条件の揃わ奴 限り?，Moore の述べるが如く，このような倨頭軟骨 腫症に対しては癌腫と同様に拔い，適時適切に腅頭摘出 衍踏切るのも必要かと思われる。

\section{結語}

69 才女の輪状軟骨より発し左披裂部に 及び㩔頭内腔

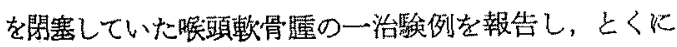
診断扰よび治療について文献的考察を行つた。

\section{文献}

1) Aschoff L.A.: Pathologische Anatomie, 664 666, Jena Verlag von Gustav Fischer. 1911.

Clerf L.H.: Chondroma of the laryx, Arch. of Otolaryng., 10, 241 247, 1929. 3) Eggston A.A. and D. Wolff: Histopathology of the Ear Nose and
Throat, 953 956, Williams and Wilkins Company. 1947. 4) Figi F.A.: Chondroma of the larynx; Report of Six cases, Ann. Otol.-rhinol.laryng., 41, 386 386, 1932. 5) Gordon B.N.: Cartilaginous tumors of the larynx Ann. Otol-rhin-laryng., 28(5), 367 375, $1918 . \quad$ 6) Hora J.F. and W.A. Weller: Laryngeal chondroma, Arch. of Oto-laryng. 74, 67 69, 1961.7 7) 海江田純，村田成美：㗋 謴 Ecchondroma の 1 症例炕 ついて。長崎医学，6巻 6 号, 833 837 面, 1927 年. $\quad$ 8) Moore Ir.: Cartilaginous tumors of the larynx, J. Laryng. and otol., 40, 9 14, 84 109, \& 145 164, $1925 . \quad$ 9) 野 中康弘：輸状軟骨の Osteochondrom を思わせた迷在

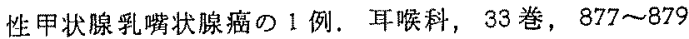
頁，1961 年. 10) Orton H.B.: Chondroma of the larynx, Ann. Otol-rhin-laryng., 50, 715 722, 1941. 11) Shiff M. and M.S. Bender: Chondroma of the larynx, Report of a case with recurrence after twenty-eight years, A.M.A. Arch. of Otolaryng. 69, 459 461, 1959. 12) Tobeck A.: Die Chondroma des Kehlkopfes, Arch. Ohren Nase Kehlkopf: 146, 79 104, 1939. 13) Walter W.L.: Chondroma of the larynx, Ann. Oto-rhino-laryg., 68(4), 1144 $1158,1959$.

穆を終るに当り，本報告について御指導，御 校閲を睗つた内海貞夫教授，病理学的飞御愁切 な御指尊を顶いた大阪市立大学神部誠一教授， さらに本症例の钼祭に終始適切な激励と御援助 を頂いた八尾市立病院長林秀雄博士を始め諸先 生に满腔の謝意を搽げきす。

本諭文の要旨は，昭和 38 年6月16日第 I7

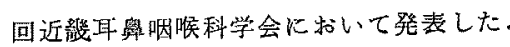

（原稳到着=昭和41.10.27日） 